\title{
Evaluation of Institutional Development : Case on Private Forest Farmer Group in Sumbawa Regency
}

Komunitas: International Journal of Indonesian Society and Culture 11(1) (2019): 99-108

DOI:10.15294/komunitas. v11i1.17580

(C) 2019 Semarang State University, Indonesia p-ISSN 2086 - 5465 | e-ISSN 2460-7320 http://journal.unnes.ac.id/nju/index.php/komunitas

\section{Dian Diniyati ${ }^{1}$}

${ }^{1}$ Institute for Research and Development for Agroforestry Technology

Received: JAnuary 9, 2019; Accepted: March 1, 2019; Published: March 30, 2019

\begin{abstract}
Although a large number of studies have been conducted to evaluate the success of farmer groups, a comprehensive evaluations starting from group formation process has not been carried out much. This research rates the success of farmer groups as a vehicle to improve the livelihoods of farmers in the area of Management Unit of Production Forest (KPHP) of Puncak Ngengas-Batu Lanteh, Sumbawa. The success was measured by evaluating three roles of farmer groups namely, a) class for learning, b) forum for collaboration, and c) unit for production. This research was conducted in two periods, i.e. on April 2016 and April 2017. The sample consisted of 20 forest farmers selected purposively, the data were collected through interviews and focus group discussion techniques and analysed descriptively. This study revealed that the roles scale of farmer groups as class for learning and as a forum for collaboration were categorized as low level, while as a unit for production was categorized as moderate level. These categories show that in general the farmer group had not succeeded in carrying out its function as a class for learning, and as a vehicle for collaboration, except as a unit for production. This weak condition was utilized by middlemen to take advantages from marketing activity by controlling forest product prices. The Kanada farmer group was categorized in the beginner group which needs $75 \%$ intervention from outsider such as continual mentoring by counsellors to grow the attitude from working alone to working together in a group.
\end{abstract}

\section{Keywords}

class for learning; farmer group; production unit; roles of group; working together

\section{INTRODUCTION}

Farmer group has been the major driving force for achieving the collective goal, particularly to enhance the livelihood of farmers. In the group, all members can interact among others, learn any new knowledge, exchange their experience, and synergize their energy. Farmer groups can be an important institution for the transformation of smallholder farming, increase productivity and incomes thereby reducing poverty (Tolno, Kobayashi, Ichizen, Esham, \& Balde, 2015).
The decision about forest product business taken individually by farmer can potentially harming farmers, particularly when facing the middlemen. This is due to the fact that most farmers have low capital resources, which generally without middlemen cannot directly deal with wholesalers (Abebe, Bijman, \& Royer, 2016). On the contrary, the decision taken by farmer collectively, by

\footnotetext{
Corresponding author

Jl. Raya Ciamis-Banjar Km 4 Pamalayan Ciamis West Java, Indonesia

Email

dian_diniyati@yahoo.com
} 
group, will enhance the bargaining power of farmer especially in catching the market opportunity, accessing the information and technology. That's the reason why, to manage forest, the availability of strong farmer group is very much needed to avoid farmers falling into disadvantages position during transaction of forest products. Improving the livelihood of farmers can be achieved through lifting the it's bargaining power by not making transactions individually, but in groups which collects farmers' aspirations (Puspitasari, 2015). If farmers join a collective that enhances their bargaining power, they tend to be better off when the group is homogeneous (Ranjan, 2017).

However, many groups of farmers cannot perform their role as a place to make their livelihood better. Moreover, the former group of farmers in KPHP Puncak NgengasBatu Lanteh experienced worse situation. Unavailability of stimulus for meeting was one of many reasons which causing the group of farmer in KPHP Puncak Ngengas closed, which was previously indicated by low frequency of member attendance in group meeting. Other causes were lack of important factors which influence the success of farmer group i.e. visionary and strong leadership (Banaszak, n.d.).

The members of farmer group in KPHP Puncak Ngengas live in the border zone inside the state forest region. This condition gives advantages for farmers to have access to both areas i.e. inside and outside of state forest region which make them unissolated. Besides, this condition make the unify effort between farmers inside with farmer outside state forest regions possible because they have already known among others. Some evidence showed that using kinship or acquaintanceship relationships enables cooperation between heterogeneous farmers (Falkowski, Chlebicka, \& Lopaciuk, 2017). Based on those characteristics together with considering the need of farmer group in this region, we have initiated to form a new group of farmer, named Kanar Dalam (Kanada).

Farmer group has an important role to push farmer's progress as member of the group. Participation in farmer groups increases yield and technical efficiency, while credit access, extension visits, and market access, influence participation in farmer groups (Abdul-rahaman \& Abdulai, 2018). The dynamical group of farmers is characterised by having activity or interaction routinely among members or with outsiders to achieve goal together. As a new group just established, the Kanar Dalam still needs help from any stakeholders to homogenize perception, sharpening the goal, and strengthening the cohesion among members. This research aimed to evaluate the coaching to farmer groups in carrying out their role as a learning class, vehicle of cooperation and as a production unit. Early information on weaknesses that occur in one or more of these roles is very important for more effective improvements of the group of farmers.

\section{METHOD}

The research was carried out in the concession of Forest Management Unit (KPH) of Kanar Luk, Production Forest Management Unit (KPHP) of Puncak Ngengas-Batu Lanteh Sumbawa, West Nusa Tenggara on April (2017 and 2018). Primary data were gathered through an interview technique using structured questionnaires and through focus group discussions (FGD). A total of 20 farmer respondents involved in the farmer group were selected purposively. The primary data consist of information associated with the role of farmer group as a class for learning, as a medium for cooperation, and as a unit for production. Meanwhile, the secondary data were obtained from relevant written reports and references.

The farmer institution was evaluated to identify how far the programs generated by farmer group can be implemented. This evaluation uses the summative assessment - a post programs evaluation - to value the result of programs implementation and to find out the achievement of programs (Suryahadi, 2007). The objects evaluated focus on the ability of group to implement the role as follow : (1) as a class for learning. (2) as a medium for cooperation, and (3) as 
a unit for production (Rustandi \& Suhadji, 2017). Data from interview and FGD were analysed by previously scoring the indicator. The assessment to evaluate the farmer institution uses the ordinal scale, i.e. very low, low, moderate, high, and very high as is shown in Table 1 . The collected data were analysed descriptively by using category as an assessment tool.

Table 1. Scoring and ranking the variables of coaching on farmer group institution

\begin{tabular}{llll}
\hline Variables & Indicator & \multicolumn{1}{c}{ Scores } & \multicolumn{1}{c}{ Ranks } \\
\hline \multirow{3}{*}{ Farmer } & Class for & $5-9$ & very low \\
group & learning & $13-17$ & low \\
coaching & & $17-21$ & moderate \\
& & $21-25$ & high \\
& Mery high \\
& cooperation & $4-8$ & very low \\
& & $12-16$ & low \\
& & $16-20$ & moderate \\
& & $20-24$ & very high \\
& Unit for & $4-8$ & very low \\
& production & $8-12$ & low \\
& & $12-16$ & moderate \\
& & $16-20$ & high \\
& & $20-24$ & very high \\
\hline
\end{tabular}

\section{RESULT AND DISCUSSION}

\section{Background behind the development of farmer group in KPHP Puncak Ngengas-Batu Lanteh}

The farmer group in the research location was developed several years ago. However, the group is now disbanded and the members are not active anymore. The only relics of the group are name plate and activities program of the group. Worse, the administrative supports and the list of members including their activity were not found too.

Based on this condition and the result of discussion with local public figure, we decided to develop new farmer group which covers member across inside and outside of KPHP Puncak Ngengas-Batulanteh RPH Kanar Luk. During the development of the group, some representatives from village officers, farmers (inside and outside KPHP region), officers from KPHP, and researchers (as facilitator) attended. The discussion started with the agreement formation on the farmer group development. The main purpose of building the group is to strengthen the community around the RPH Kanar Luk to improve their livelihood.

This group was developed to introduce the cultivation programs of firewood energy such as kaliandra (Calliandra calothyrsus) and akor (Acacia auriculiformis). After recognising the predominance of firewood species, hopefully the community will continue developing the species on their land. When the program accomplished, the next programs is introducing social engineering in the form of training on the honey bee cultivation by member itself. Through this social engineering, hopefully the sense of belonging will raise participation, and creativity development. This honey bee cultivation training was chosen because the potential of bee trigona in the Kanar Luk RPH area is quite high. In addition, the market for honey in the Sumbawa Regency is quite competitive both at the local and regional market levels. This is also supported by the willingness of the Puncak Ngengas KPHP Office - Batu Lanteh to absorb honey produced by farmer groups.

The development of farmer group aimed to provide place for farmers to get various training including firewood energy which enables farmers create other jobs that are not depending on the existence of forests. Therefore, the source of incomes by farmers will be more diverse and the total income will be increased too. The farmer group was developed by using domicile approach whereas the farmer has well known among others (Nuryanti \& Swastika, 2011). The amounts of members are limited up to 20 farmers whereas according to (Cahyono \& Tjokropandoyo, 2013) such amount is an ideal size (20-25 people). This limited number hopefully will create dynamic condition in the group as well as will enhance the participation of all members. In addition, the caretakers of the group will be easier to mobilise members for actively participating in the group activities. This new established group can hopefully be the core of firewood development activity in KPHP Puncak 
Ngengas-Batulanteh, and can give positive effect to other community. At the end, other plasma groups will also grow and interested in developing firewood energy.

The new established farmer group, the Kanar Dalam, more prioritize in honey production especially from trigona bee species than cultivation of firewood energy due to its high potency and market chance. While firewood species (kaliandra) can be taken as a source of bee forage of Trigona bee. However, a chief of KPHP Puncak Ngengas_Batulanteh, Zulkarmaen (personal communication, November 7,2017$)$ revealed that kaliandra wood was highly demanded by European industries for making briquettes. This information indicates that kaliandra and trigona honey both have good market chance. The organisation structure of the group comprises of chairman, secretary, treasurer, and business division. This complete structure (Peraturan Menteri Pertanian No: 273 year 2007) may encourage the members for active in organisation.

\section{Performance Building of Farmer Group}

This performance is needed to stimulate the togetherness among members of farmer group as well as to show programs (goal, ex- pectation, planning, and budgeting) to all members of group. This performance building hopefully will give positive motivation to farmers particularly in participating in the organisation. Each member must understand the goal, the expectation and the working programs of the group. Based on the discussion, the performance of the organisation has been performed as is shown in Table 2.

Setting the goals and activities of group are the important things that have been done by the group. Those designed activities would be managed based on the agreement among members whereas the activities are selected based on similarity of interest, availability of natural resources, condition of social-economic of members, familiarity, trust, and relationship harmony among famers which then can be used as a bounded factor for sustainability of organisation life (Hermanto \& Swastika, 2011).

Farmers interested to join in the group because there is an expectation to increase their incomes by receiving training and extension from the group to develop agribusiness, therefore the farmers do not work as stone breakers and sand collector anymore (Diniyati, 2015). The improvement of incomes, more jobs, new business and coope-

Table 2. Growth performance for institution of farmer group

\begin{tabular}{|c|c|c|}
\hline No & Criteria & Farmer group (Kanada) \\
\hline \multirow[t]{2}{*}{1} & Aim & Increase the income \\
\hline & & Broaden the type of jobs (not merely as a stones searcher) \\
\hline \multirow[t]{3}{*}{2} & Expectation & All members of group become solid \\
\hline & & Group progressed and developed \\
\hline & & $\begin{array}{l}\text { Group becomes a model to improve income for community of } \\
\text { Kanar Dalam }\end{array}$ \\
\hline \multirow[t]{3}{*}{3} & Working plan & $\begin{array}{l}\text { Cultivate bees forage (Caliandra spp) at road side and house } \\
\text { yard in December } 2017\end{array}$ \\
\hline & & $\begin{array}{l}\text { Looking for Trigona nest for the queen of Trigona bee (every } \\
\text { time going to the field) }\end{array}$ \\
\hline & & Practise moving out the trigona (January 2018) \\
\hline 4 & Budged sources & $\begin{array}{l}\text { From obligatory contributions of member (IDR } 5,000 / \text { month/ } \\
\text { member) }\end{array}$ \\
\hline \multirow[t]{3}{*}{5} & Opportunity & With village (if the business is visible and proven) \\
\hline & for cooperation & $\begin{array}{l}\text { KPH Puncak Ngengas Batu Lanteh (group coaching and trigona } \\
\text { honey marketing) }\end{array}$ \\
\hline & & Shops and stalls around Sumbawa \\
\hline
\end{tabular}


ration building indicate the local economy is growing (Cahyono \& Tjokropandoyo, 2013). Join in the farmer group discourage farmers to collect stone and sand because those kinds of jobs are very labour consuming but low income.

To implement the organisation programs such as meeting, producing honey stup etc. need budget. According to result of discussion, they agree to collect budget from the obligatory contribution by members and hopefully all members will have sense of belonging to the group. For preliminary administration system, one farmer was selected to collect obligatory contribution from members and the collected contribution furthermore are deposited to treasurer and reported to the head of the farmers group.

Due to new group, the members have not known yet the join opportunity which can be done. For the time being, all members agree to build cooperation with village government, KPHP and other government institution as well as with near shop and stall.

\section{Farmer Group Development}

One of the characteristics of a dynamic farmer group is the existence of activities or interactions that are carried out routinely between fellow group members or outside parties so that group goals are achieved. However, activities or interaction in the farmer group of the Kanada is rarely carried out, the farmers have apathies of existence of farmer group due to many unaccomplished promises by local government. Besides, the caretakers are getting less actives encourage members to implement committed activities. Actually, the caretakers were elected by acclamation in the meeting by all members.

An effort to activate group is that by conducting a field school to learn cultivation of honeybees cultivation particularly Trigona bees. Honey from wild is a seeded non timber forest product (NTFP) and has a strategies value to support economic activity of community, especially for people around the forest (Hidayatullah, Handoko, Maring, \& Ramdiawan, 2017). This activity is a part of group strengthening, where groups are given alternative activities that can generate income.

Honey bees cultivation has been practised by many farmers despite the fact that not all of them can work well. There were $30 \%$ of farmers who have tried to cultivate honey bees but have not succeeded, on the contrary there were $25 \%$ of farmers who have carried out honey bee cultivation activities and succeed, while the remaining $45 \%$ of farmers have never cultivated honey bees. The main obstacle to the development of honey bees is forage, especially during the dry season because many plants do not flower, thus making it difficult for farmers to find food for their bees.

The formation of farmer group is not an easy job, because it combines many perspective of many people become one. There are several sequence steps to be carried out by member to form of good farmer group, start from getting to know each other, respect each other, accept each other, co-operate with each other, support each other, link with each other, and co-ordinate with each other. The training of honey bees cultivation aimed to make farmers do not lean on wild honey alone.

At this time, the community is still looking for honey from natural forests, it is still rare to cultivate it so that the results obtained are facultative. But if this honey bee can be cultivated by members of the farmer group, the results will be obtained continuously. Forest honey hunting is done twice a year, between March to May and September to December every year, the period of October - December generally gets more results (Hidayatullah et al., 2017).

This field school activity according to farmers is very beneficial (70\%) because of increased knowledgeabout the development of honey bee cultivation where farmers can directly see the technique of honey bee development. Meanwhile 30\% of farmers responded that field schools were quite useful because they had previously participated in training on honey bee development before so the knowledge gained was not too significant. However, farmers continue to attend 
the field school activities because they want to know and remind them of honey bee cultivation techniques as well as to discuss with the expert.

All farmers agree that honey bee cultivation is an easy work to practice, because they have known honeybees since they were young. But now the honey bee activity must be cultivated. The change in activity requires patience from farmers so that the activity of honey bee cultivation is successful. Farmers believe that honey bee activity can provide income continuously. The response of farmers to honey bee cultivation is diverse, there are those who directly accept and some who discuss it first with family members. Therefore, it is expected that after participating in the development activities of honey bee cultivation there are group members who want to develop the honey bee cultivation as pioneers so that later can be followed by all group members. For this reason, what is needed by the Kanar Dalam Farmer Group is continuous assistance which makes this activity can truly be carried out.

\section{Preliminary evaluation of farmer group institution}

Assessment of success of coaching to enhance the skill of farmer group must go through evaluation. Evaluation is conducted to know how far their plans have been carried out in accordance with the agreed time schedule. Evaluation can be carried out by comparing planning with the result and the effect of coaching to farmer group (Rustandi \& Suhadji, 2017). The object of evaluation is focused on the ability of farmers to conduct their roles in the following items i.e. (1) class for learning, (2) medium for cooperation, and (3) unit for production.

Evaluation aimed to identify the participation of member of farmer group in achieving the collective goal. In the teaching and learning activities, participation plays important function in the improving of ability, knowledge, skill and attitude to build cooperation among member or with other parties to make the business by group become stronger and more economic. The members of this farmer group are business owners who can be developed to achieve economies of scale both in terms of quantity and continuity. Institution of farmer groups around RPKH Kanar Luk in 2017 has made a work plan that will be implemented by all members of the farmer groups, as shown by Table 1 . But the work plan that has been made has not been fully implemented. Almost all members of the farmer group have not planted bee forage (kaliandra), although the seeds have been provided and distributed free of charge to all members of the farmer group. Each member of the farmer group is given 5 poly bag seeds.

The reason for not planting kaliandra for fear of the plants being eaten by livestock such as goats and cows. This condition has happened to members of the farmer group who have planted kaliandra around his house but eaten by goats. As a result, the interest of other group members decreased to plant kaliandra plants. In addition, the culture of planting timber plants among members of the farmer groups does not yet exist, generally still more happy to plant annual crops that produce quickly and can be consumed immediately. Another plan that has not been realized is the creation of honey stalls for each member which was only carried out by 6 members. The age factor of this young farmer group also causes group activities still cannot be carried out effectively, whereas the role and effectiveness of farmer institutions are influenced by the age factor of the institution and the attitude factor of farmers in accepting changes (Cahyono \& Tjokropandoyo, 2013). Although the age of the farmer group is still young, it is still necessary to evaluate it to better understand the activities of the farmer groups that have been formed, including:

\section{Farmer group as a class for learning}

The purpose of establishing a farmer group around RPH Kanar Luk is as a vehicle to improve the welfare and independence of the community so that it is not dependent on forest resources. Furthermore, it is expected to increase income which can create economic independence for the community 
around the forest area. The efforts carried out are by conducting training, counselling and comparative studies. This farmer group, therefore, can be used as a class for learning, where members can do teaching and learning activities, exchange experiences and discuss to further increase their productivity so that a prosperous life can be achieved. Evaluation of farmer groups as learning classes is shown in Table 3 .

Farmers' assessment of the role of farmer groups as a learning class is low (12.5). This means that the farmer group has not been able to act as a class for learning which can increase the knowledge and skills of its members, or the members have not felt the benefits of the farmer group as a class for learning. Farmer groups around RPH Kanar Luk have not been able to realize their function as class for learning in accordance with Permentan No. 273 of 2007 , namely as a place for teaching and learning for its members in order to increase knowledge, skills and attitudes as well as the growth and development of self-reliance in farming. Thus, productivity and income increase which result the life is more prosperous.

The main cause of the member of the farmer group rarely attend the meeting is the lack of understanding of members about the benefits of farmer groups. As a result, the commitment of the members was very low, this condition could be seen at the time of the meeting or training, whereas very few members were present. The reason raised by farmers for not being able to attend the meeting is a cliché problem, namely finding income to meet the daily needs of their families. This reason is also used by the group leader so that they do not actively mobilize their members to hold regular meetings. Finally, there were never regular meetings and this caused group independence to be low. Actually, if the members and chairman of the Kanar farmer group have a commitment to be more advanced and independent, then these obstacles can be overcome. The characteristics of a strong and independent farmer group, one of which is the meeting of members / board meetings held regularly and continuously (Koampa, Benu, Sendow, \& Moniaga, 2015). However, the fact is that group meetings can be held and attended by group members if there is a stimulus that is given directly to group members.

\section{Farmer group as a vehicle for collabo- ration}

Membership of farmer groups is formed based on domicile, where the place of residence is close together so they already know each other. This condition has a positive impact which is facilitating in terms of coaching . Domicile proximity makes farmers easier to interact each other, whether in agricultural, forestry or other social activities. This condition becomes social capital for farmers to work together. According to Permentan No. 273 of 2007 the farmer group is a place to strengthen cooperation among farmers, in the group of farmer and between group of farmer and also with other parties. Through this collaboration, farming is expected to be more efficient and able to deal with threats, challenges, obstacles and disturbances. But in reality the collaboration is difficult to practice by farmers, the cooperation is usually no longer an activity of mutual assistance but rather a business activity that has to come with profit. Evaluation of

Table 3. Farmer groups as class for learning

\begin{tabular}{llccccc}
\hline No & Criteria & $\begin{array}{c}\text { Frequency } \\
\text { (people) }\end{array}$ & $\begin{array}{c}\text { Percentage } \\
(\%)\end{array}$ & Total score & Average & $\begin{array}{c}\text { Score } \\
\text { category }\end{array}$ \\
\hline 1 & Very low & 5 & 25 & 25 & 0 & \\
2 & Low & 5 & 25 & 50 & 10 & Low (12.5) \\
3 & Moderate & 5 & 25 & 75 & 15 & \\
4 & High & 5 & 25 & 100 & 20 & \\
5 & Very high & 0 & 0 & 0 & 0 & \\
& Total & 20 & 100 & 250 & 12.5 & \\
\hline
\end{tabular}


farmer groups as a vehicle for collaboration can be seen in Table 4 .

The assessment of group functions as a vehicle for collaboration is included in the low category $($ score $=10)$. This shows that the group has not been able to carry out its function as a vehicle for cooperation, either cooperation between members or cooperation with outside parties. To increase productivity, group members still work individually. There is a tendency for farmers to prioritize their individual interests than group interests. In addition, the group leader has not been able to play an active role in mobilizing its members to make the cooperation and the group meeting routinely possible so that the goal of group can be achieved. This condition is not much different from the findings by (Ruhimat, 2015) in Ciamis Regency, West Java, that the role of farmer groups as a vehicle for collaboration, class for learning and unit for production are not optimal. Even though the optimization of the three roles are able to improve the skills, learning experience and knowledge of farmers in managing their farming. (Hermanto \& Swastika, 2011)(Ruhimat, 2015). This weakness in terms of unity in the group makes their ability to marker their forest product weak too. This opportunity is usually used by middle- men to control prices in the transaction of forest product.

\section{Farmer group as unit for production}

Farmer group is one of the drivers of the economy for rural communities, where farmers who are members of the group can be independent so that they can determine the commodities to be cultivated, markets, business partners and commodity prices. But in reality there are still many farmer groups that have not been able to play a role as a forum for the community to improve their welfare. This is due to the low level of awareness of the members in implementing group agreements and decisions, the non-functioning of the treasurer and group secretary, the non-functioning of group fees, and low human resources (Ginting \& Fauzia, 2012). Although the farmer groups in the RPH Kanar Luk area belong to the category of the beginner class farmer group, however the group has made an agreement on production activities that can be carried out by its members. For this reason, an evaluation is needed to determine the role of the group in these activities as is shown in Table 5 .

Analysis using the score category resulted that the function of the farmer group as a production unit included in the me-

Table 4. Evaluation of farmer groups as a vehicle for collaboration

\begin{tabular}{llccccc}
\hline No & Criteria & $\begin{array}{c}\text { Frequency } \\
\text { (people) }\end{array}$ & $\begin{array}{c}\text { Percentage } \\
(\%)\end{array}$ & Total score & Average & Score category \\
\hline 1 & Very low & 0 & 0 & 0 & 0 & \\
2 & Low & 10 & 50 & 80 & 8 & \\
3 & Moderate & 10 & 50 & 120 & 0 & Low $(10)$ \\
4 & High & 0 & 0 & 0 & 0 & \\
5 & Very high & 0 & 0 & 0 & 0 & \\
\hline & Total & 20 & 100 & 200 & 10 & \\
\hline
\end{tabular}

Table 5. Evaluation of Farmer Groups as unit for production

\begin{tabular}{clccccc}
\hline No & Criteria & $\begin{array}{c}\text { Frequency } \\
\text { (people) }\end{array}$ & $\begin{array}{c}\text { Percentage } \\
(\%)\end{array}$ & Total score & Average & Score category \\
\hline 1 & Very low & 4 & 20 & 16 & 4 & \\
2 & Low & 7 & 35 & 112 & 56 & \\
3 & Moderate & 6 & 30 & 72 & 12 & Moderate (13) \\
4 & High & 3 & 15 & 60 & 20 & \\
5 & Very high & 0 & 0 & 0 & 0 & \\
\hline & Total & 20 & 100 & 260 & 13 & \\
\hline
\end{tabular}


dium category (13), indicates that the farmer group has been able to run its production unit but has not run continuously and has not been in accordance with the needs of the members. This medium category also shows that most members of farmer groups have the ability to develop businesses in groups, one of which is honey bee keeping. Based on Permentan no 273 of 2007 , farmer groups as production units, namely farming carried out by each member of the farmer group, as a whole must be seen as a business entity that can be developed to achieve economies of scale, in terms of quantity, quality and continuity.

Every member of the farmer group has their own business, both working in the fields, forests, trading, collecting rocks and sand, truck drivers (dumbstruck), looking for honey in the forest and others. Unfortunately, there is no synergy in running the business, members generally run businesses individually so they have not been able to achieve economies of scale and cannot improve their welfare. The work carried out by farmers is generally an instant job that is directly generating money. Most members do not have patience in waiting for the process of obtaining results from production activities, therefore it is still very difficult for farmers to be able to cooperate in carrying out production activities. Collaboration between group members can be done if there is a facilitator (companion).

\section{CONCLUSION}

The Kanar Dalam was categorized as a beginner farmer group which was built based on collective goal and desire of farmers around RPH Kanar Luk. The organisation structure of the group comprises of chairman, secretary, treasurer and 20 members who live close together. Although beginner, they successfully generate the performance of the group e.g. collective goal, group expectations, working plan, and budget.

To more activate the farmer group, the group had been introduced by practising a field study on honey bee cultivation. The honey bee business was selected because it was potential to support the income of farmer as well as the development of firewood energy (kaliandra and akor) and it had good markets. This activity have a chance to success when all members commit to conduct honey bee cultivation and the caretakers actively motivate members.

To identify the success of the group in carrying out its role in the improvement of farmers livelihood, three functions of group e.g. class for learning, vehicle for working together, and unit for production had been evaluated. The result showed that the function of the farmer group as a class for learning and as a vehicle for working together were categorized as low leve, while the function of the group as a unit for production was categorized as moderate level. These categories indicated that in general the farmer group do not implement their functions yet as class for learning and as a vehicle for working together except as a unit for production. This weak condition was potentially utilized by middlemen to take advantages from marketing activity by controlling forest product prices. The Kanada farmer group was categorized in the beginner group which needs $75 \%$ intervention from outsider such as continual mentoring by counsellors to grow the attitude from working alone to working together in a group.

\section{ACKNOWLEDGMENTS}

The authors were gratefully indebted to the Institute for Research and Development on Agroforestry Technology which has financed the research. The authors also would like to convey a high appreciation to consecutively the Head and Staffs of (the Forest Management Unit of Puncak Ngengas-Batulanteh and local government) who have accompanied us in the field during research activity. Similar appreciation was also extended to the communities (farmers, traders, industry owners) who were all enthusiastically quite willing to follow the entire stages of research activities and to the forestry technicians for their valuable assistances in collecting the field. 


\section{REFERENCES}

Abdul-rahaman, A., \& Abdulai, A. (2018). Do farmer groups impact on farm yield and efficiency of smallholder farmers? Evidence from rice farmers in northern Ghana. Food Policy Journal, (October).

Abebe, G. K., Bijman, J., \& Royer, A. (2016). Are middlemen facilitators or barriers to improve smallholders $\hat{a} €^{\mathrm{TM}}$ welfare in rural economies? Empirical evidence from Ethiopia. Journal of Rural Studies, 43, pp. 203-213. http://doi. org/10.1016/j.jrurstud.2015.12.004

Banaszak, I., 2008. Determinants of successful cooperation in agricultural markets: evidence from producer groups in Poland. In Strategy and Governance of Networks (pp. 27-46). PhysicaVerlag HD

Cahyono, S., \& Tjokropandoyo, D. S. (2013). Peran Kelembagaan Petani Dalam Mendukung Keberlanjutan Pertanian Sebagai Basis Pengembangan Ekonomi Lokal. Jurnal Perencanaan Wilayah Dan Kota, 2(1), pp.15-23.

Diniyati, D. (2015). Ragam Pekerjaan Petani Penggarap di RPH Kanar Luk Wilayah KPHP Batulanteh, Kabupaten Sumbawa. In inovasi agroforestry mendukung kemandirian bangsa (pp. 720-725).

Falkowski, J., Chlebicka, A., \& Lopaciuk G.B. (2017). Social relationships and governing collaborative actions in rural areas: Some evidence from agricultural producer groups in Poland. Journal of Rural Studies Journal, 49(1305), pp. 104-116.

Ginting, I. M., \& Fauzia, L. (2012). Studi Perbandingan Natara Kelompok Tani kelas Pemula dengan kelompok tani kelas Madya di Kabupaten Aceh Tamiang. Program Study Agribisnis, USU.

Hermanto, H., \& Swastika, D. K. S. (2011). Penguatan Kelompok Tani: Langkah Awal Peningkatan Kesejahteraan Petani. Analisis Kebijakan Pertanian, 9(4), pp. 371-390.

Hidayatullah, M., Handoko, C., Maring, A. J., \& Ramdiawan, R. (2017). Kondisi Sosial Ekonomi
Masyarakat Pemburu Madu Hutan di Dusun Arung Santek, Pulau Moyo. In Prosiding Seminar Nasional dalam rangka Dies Natalis Ke 42 UNS.

Koampa, M. V., Benu, O. L. S., Sendow, M. M., \& Moniaga, V. R. B. (2015). Partisipasi Kelompok Tani Dalam Kegiatan Penyuluhan Pertanian Di Desa Kanonang Lima, Kecamatan Kawangkoan Barat. ASE, $11(3 \mathrm{~A})$, pp. 19-32.

Nuryanti, S., \& Swastika, D. K. S. (2011). Peran Kelompok Tani Dalam Penerapan Teknologi Pertanian. Forum Penelitian Agro Ekonomii, 29(2), pp. 111-128.

Puspitasari, A. W. (2015). Farmer' s Prosperity : How to Increase Farmer's Bargain Power ( In Islamic Perspective ). Procedia - Social and Behavioral Sciences, 211(September), pp. 455-46o. http://doi.org/10.1016/j.sbspro.2015.11.06o

Ranjan, R. (2017). Challenges to Farm Produce Marketing : A Model of Bargaining between Farmers and Middlemen under Risk. Journal of Agricultural and Resource Economics, 42(3), pp. 386-405.

Ruhimat, I. S. (2015). Tingkat motivasi petani dalam penerapan sistem agroforestry. Jurnal Penelitian Sosial Dan Ekonomi Kehutanan, 12(2), pp. 131-147.

Rustandi, Y., \& Suhadji, R. (2017). Keragaan Evaluasi Fungsi Kelembagaan Kelompok Tani Di Kecamatan Papar Kabupaten Kediri Jawa Timur. Agrica Ekstensia, 2(2), pp. 55-6o.

Suryahadi, A. (2007). Modul 4 : Persyaratan dan Unsur-unsur Evaluasi yang baik. In Kumpulan Bahan Latihan Pemantauan Evaluasi Programprogram Penangulangan Kemiskinan. Jakarta: Bappenas.

Tolno, E., Kobayashi, H., Ichizen, M., Esham, M., \& Balde, B. S. (2015). Economic Analysis of the Role of Farmer Organizations in Enhancing Smallholder Potato Farmers ' Income in Middle Guinea. Journal of Agricultural Science, 7(3), pp. 123-137. http://doi.org/10.5539/jas. v7n3p123 